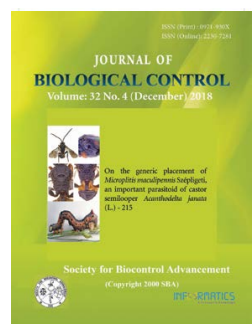

\title{
Effect of inundative releases of Trichogramma chilonis in sugarcane
}

\author{
M. VISALAKSHI ${ }^{*}$ and B. BHAVANI \\ Regional Agricultural Research Station, Acharya NG Ranga Agricultural University, Anakapalle - 531 001, \\ Andhra Pradesh, India \\ *Corresponding author E-mail: visalamahanthi@yahoo.co.in
}

\begin{abstract}
Studies on effect of inundative releases of Trichogramma chilonis in sugarcane revealed that the frequency and rate of T. chilonis release had played a significant role in the management of sugarcane shoot borers. Early shoot borer and internode borer incidence was low in T. chilonis@75,000/ha/release, 6 times $(6.54 \%$ and $2.27 \% ; 3.92 \%$ and 5.85\%) followed by T. chilonis @ 50,000/ha/release, 6 times (7.9\% and 4.26\%) whereas untreated control recorded high incidence of early shoot borer and internode borer (10.94\% and $15.95 \% ; 5.12 \%$ and $18.25 \%$ ) during 2015 and 2016. The sustainability of inundative releases of T. chilonis with highest per cent field recovery was recorded in T. chilonis release @ $975,000 /$ ha/release, 6 times during monsoon period (68.63\% and 20\%) and post monsoon period (29.55\% and $37.59 \%$ ) as compared to pre monsoon period (12.1\% and $9.27 \%$ ) of 2015 and 2016. Cane yields recorded in plant crop, 2015 (52.42 t/ha) and ratoon crop, 2016 (47.95 t/ha) revealed that high rate of T. chilonis @ 75,000/ha/release resulted in increased yields (21.77\% and 24.64 $\%)$ over untreated control.
\end{abstract}

KEY WORDS: Field recovery, inundative releases, Trichogramma chilonis

(Article chronicle: Received: 07-10-2019; Revised: 11-02-2020; Accepted: 15-02-2020)

\section{INTRODUCTION}

Sugarcane shoot borers have become challenging pests of sugarcane crop due to their feeding habit inside the plant parts where sprays are difficult to reach. Indiscriminate use of pesticides results in mortality of natural enemies resulting in flare up of pest population. Inundative releases of the bioagents for the control of lepidopterous pests are being practiced in more than 32 million hectares each year around the world. Trichogramma chilonis release reduced the damage up to $70-92 \%$ on sugarcane, corn and cotton crops in China, Switzerland, Canada. Narasimha Rao et al. (2006) reported that four releases of T. chilonis @ 50,000/ ha/release from 30 days after planting at 7-10 day interval were effective in borer management in sugarcane. Biological control of early shoot borer, Chilo infuscatellus (Snellen) and internode borer, Chilo sacchariphagus indicus (Kapur) in sugarcane through inundative releases of the egg parasitoid, T. chilonis Ishii is being practiced in sugarcane cultivated tracts in India and it has also received considerable attention in Andhra Pradesh. Many pests proliferate during specific seasons with natural enemies co-occurring. Early shoot borer attacks the crop in its early stages of growth with peak activity during summer months. The pest infestation is generally high during pre-monsoon period (April-June) when high temperature prevails and its activity decreases with the onset of south west monsoon. Internode borer attack is more in the monsoon and post monsoon periods. Several reports are available on the varied degree of parasitism (2-95\%) by Trichogramma spp. after release. However, information is sparse on the recovery of the parasitoids in sugarcane ecosystem. Effective dispersal distance was studied based on the recovery of $T$. chilonis in sugarcane. Hence, it is highly essential to study the feasibility of inundative releases of $T$. chilonis against sugarcane shoot borers.

\section{MATERIALS AND METHODS}

Field experiments were conducted at Regional Agricultural Research Station, Anakapalle using sugarcane variety 2001A56 during 2015-16 planted crop during April 2015 and during 2016-17 ratoon crop planted in April 2016 to study the effect of inundative releases of T. chilonis recommended for management of shoot borers infesting sugarcane in Andhra Pradesh. The Biocontrol agent, T. chilonis (National accession no. NBAII-MP-TRI-13) supplied by NBAIR, Bangalore was multiplied in the Biocontrol Laboratory, AICRP on Biological control, Regional Agricultural Research Station, Anakapalle, Andhra Pradesh. Trichogramma chilonis was released at two rates of release, i.e., 50,000/ha/week and 75,000/ha/week. The number of releases was 4 and 6 from 30 days after planting and two at node formation in different blocks. The unreleased experimental block was treated as control. Egg cards 
(10 $\mathrm{cm} \times 2.5 \mathrm{~cm})$ containing $T$. chilonis parasitized eggs were cut into small pieces and placed uniformly in each block at 30 days after planting for adequate dispersal of the parasitoid. The subsequent releases were made at weekly intervals.

There were four treatments as blocks with different dosages and timing of $T$. chilonis release as Block 1: Release of T. chilonis@50,000/ha/week, 4 times from 30 Days After Planting (DAP) and two times at node formation at 7-10 day interval; Block 2: Release of T. chilonis @ 50,000/ha/week, 6 times from 30 (DAP) and two times at node formation at 7-10 day interval; Block 3: Release of T. chilonis @ 75,000/ha/week, 4 times from 30 DAP and two times at node formation at 7-10 day interval and Block 4: Release of T. chilonis@75,000/ha/week, 6 times from 30 DAP and two times at node formation at 7-10 day interval with Block 5: No release of T. chilonis as untreated control with five replications. Data on cumulative incidence of early shoot borer as \% Dead Heart (DH) was recorded from 45 days to 120 days after planting. Percent incidence of internode borer was recorded from 10 randomly selected canes from each replication in all the blocks at harvest. The establishment of the parasitoid in sugarcane ecosystem was assessed on the basis of occurrence of early shoot borer damage as dead hearts during crop growth period and internode damage at harvest in all blocks with $T$. chilonis release at different rates and frequencies.

The field recovery of the parasitoid was studied by using Corcyra egg cards as sentinel cards as stem borer eggs were not available in the field abundantly throughout the year for studying the field recovery of the egg parasitoid, T. chilonis. Corcyra egg cards of 100 eggs as sentinel cards were kept in the field at a distance of one metre from the point of release after a day of $T$. chilonis release in five replications of all the blocks/treatments. Recovery of field populations of T. chilonis was assessed during premonsoon period (April, June), monsoon period (July) and post monsoon period (September, October) during 2015-16 and 2016-17. The field recovery of the parasitoid and cane yield increase over untreated control was calculated.

\section{RESULTS AND DISCUSSION}

Data on early shoot borer (ESB) and internode borer (INB) damage along with field recovery of Trichogramma chilonis during 2015 and 2016 are presented in Table 1 and 2.

During 2015, the data on early shoot borer damage $(\% \mathrm{DH})$ and internode borer damage (\%) revealed that the releases of $T$. chilonis had played a significant role in the reduction of shoot borers in sugarcane (Table 1). Block 4 recorded significantly lower per cent dead heart (6.54) and internode borer damage (3.92) followed by block 3 (7.62 and 4.21) indicating that the parasitoid establishment was good with higher dosage and more number of releases. Whereas, untreated control block recorded the highest per cent DH $(16.6 \%)$ and internode borer damage (8.62\%). Similar results were recorded during 2016, which showed that lowest per cent dead heart (2.27) and inter node borer damage (5.85) was observed in Block 4 and highest per cent in untreated control (15.95\%DH and 18.25\%) (Table 2).

The highest per cent recovery of egg parasitoid, T. chilonis in block 4 during monsoon period (July, $2015-68.63 \%$ ) ; post-monsoon period (September, 15-29.55\% ) and premonsoon period (June,15-12.1\%) compared to other blocks indicated that the establishment of parasitoid was high in block 4 due to release of parasitoid at higher dosage and frequency. Higher recovery rate of $T$. embryophagum was recorded during October and November months in Taiwan corn fields infested by Asian corn borer (Bing \& Jih, 1996). Jalali and Singh (2006) reported that natural enemies like T. chilonis can perform effectively in areas where the temperature ranges between $18^{\circ}$ and $32^{\circ} \mathrm{C}$ rather than in other areas. Parasitoid recovery was low in block 1 during monsoon period (June, $2015-2.89 \%$ ) and post-monsoon period (July, 15-4.13 and in September, 15-2.07\%) and was negligible in control block (0.0- $0.43 \%$ ) during monsoon and post-monsoon periods. Similarly, the highest per cent recovery of the parasitoid was in block 4 during post-monsoon period (October, 16), where highest percent recovery $(37.59 \%)$ was recorded probably due to better establishment of the parasitoid compared to pre-monsoon (June, $16-9.27 \%$ ) and monsoon periods (June, $16-17.47 \%$ and July, $16-20 \%$ ). Significantly higher parasite recovery during post-monsoon period of crop (Grand growth stage) was in blocks treated with 6 releases of T. chilonis@ $@ 75,000 /$ ha/release from 30 days after planting and 2 times at node formation at weekly interval during both the years of study. Similar results reported that the variation in per cent recovery of parasite during the two years of study could be due to combined effect of climatic factors and plant physical factors which changes with the stage of the crop. The major climatic factors that determine the activity of any insect are temperature, relative humidity and rainfall (O’Malley, 2005). Somchoudhury and Dutt (1980) reported that mild climatic conditions were most favourable for T. chilonis (=australicum Girault) and T. perkinsi Girault resulting in significant increase in their parasitizing ability (Bing \& Jih, 1996). Similar results indicated that dry season favourable for establishment and recovery of $T$. chilonis in paddy varieties (Das, 2004). Jalali et al. (2006a) worked on adaptive performance of $T$. chilonis at low temperature $\left(18^{\circ}-24^{\circ} \mathrm{C}\right)$ and reported that a strain adapted to low temperature parasitized $58 \%$ of Corcyra cephalonica eggs 
Table 1. Relative percentage of Trichogramma chilonis recovered from egg masses of sentinel cards during 2015

\begin{tabular}{|c|c|c|c|c|c|c|c|}
\hline \multirow{3}{*}{ Treatment } & \multirow{3}{*}{$\begin{array}{c}\text { ESB } \\
(\% \mathrm{DH})\end{array}$} & \multirow{3}{*}{$\begin{array}{c}\text { INB } \\
\text { damage } \\
(\%)\end{array}$} & \multicolumn{3}{|c|}{ T. chilonis field recovery (\%) } & \multirow{3}{*}{$\begin{array}{l}\text { Cane } \\
\text { yield } \\
(\mathrm{t} / \mathrm{ha})\end{array}$} & \multirow{3}{*}{$\begin{array}{c}\text { Yield } \\
\text { Increase } \\
(\%)\end{array}$} \\
\hline & & & $\begin{array}{c}\text { Pre- } \\
\text { monsoon } \\
\text { period } 2015\end{array}$ & $\begin{array}{c}\text { Monsoon } \\
\text { period } \\
2015 \\
\end{array}$ & $\begin{array}{c}\text { Post- } \\
\text { monsoon } \\
\text { period } 2015\end{array}$ & & \\
\hline & & & $\begin{array}{l}\text { First week } \\
\text { June }\end{array}$ & $\begin{array}{c}\text { Last } \\
\text { week July }\end{array}$ & $\begin{array}{l}\text { Last week } \\
\text { Sep-tember }\end{array}$ & & \\
\hline $\begin{array}{l}\text { T1: T. chilonis release } \\
\text { @ } 50,000 / \text { ha/release, } 4 \\
\text { times from } 30 \text { days after } \\
\text { planting and } 2 \text { times at } \\
\text { node formation at } \\
\text { weekly interval }\end{array}$ & $10.94^{b}$ & $5.12^{\mathrm{b}}$ & $\begin{array}{c}2.89 \\
(1.836)^{\mathrm{a}}\end{array}$ & $4.13^{\mathrm{c}}$ & $\begin{array}{c}2.07 \\
(2.55)^{\mathrm{c}}\end{array}$ & $48.46^{\mathrm{c}}$ & 12.57 \\
\hline $\begin{array}{l}\text { T2:T. chilonis release } \\
@ 50,000 / \text { ha/release, } 6 \\
\text { times from } 30 \text { days after } \\
\text { planting and } 2 \text { times at } \\
\text { node formation at } \\
\text { weekly interval }\end{array}$ & $7.9^{\mathrm{c}}$ & $4.26^{\mathrm{b}}$ & $\begin{array}{c}3.1 \\
(1.836)^{\mathrm{b}}\end{array}$ & $48.92^{\mathrm{b}}$ & $\begin{array}{c}14.66 \\
(3.891)^{b c}\end{array}$ & $49.22^{\mathrm{b}}$ & 14.33 \\
\hline $\begin{array}{l}\text { T3:T. chilonis release } \\
\text { @ } 75,000 / \text { ha/release, } 4 \\
\text { times from } 30 \text { days after } \\
\text { planting and } 2 \text { times at } \\
\text { node formation at } \\
\text { weekly interval }\end{array}$ & $7.62^{\mathrm{c}}$ & $4.21^{\mathrm{b}}$ & $\begin{array}{c}6.32 \\
(1.836)^{c}\end{array}$ & $53.3^{\mathrm{b}}$ & $\begin{array}{c}19.86 \\
(4.508)^{\mathrm{ab}}\end{array}$ & $50.0^{\mathrm{b}}$ & 16.14 \\
\hline $\begin{array}{l}\text { T4:T. chilonis release } \\
\text { @ } 75,000 / \text { ha/release, } 6 \\
\text { times from } 30 \text { days after } \\
\text { planting and } 2 \text { times at } \\
\text { node formation at } \\
\text { weekly interval }\end{array}$ & $6.54^{\mathrm{c}}$ & $3.92^{\mathrm{b}}$ & $\begin{array}{c}12.1 \\
(1.836)^{\mathrm{c}}\end{array}$ & $68.63^{\mathrm{a}}$ & $\begin{array}{c}29.55 \\
(5.475)^{\mathrm{a}}\end{array}$ & $52.42^{\mathrm{a}}$ & 21.71 \\
\hline T5:Untreated control & $16.6^{\mathrm{a}}$ & $8.62^{\mathrm{a}}$ & $\begin{array}{c}0.0 \\
(1.836)^{\mathrm{d}}\end{array}$ & $0.43^{c}$ & $\begin{array}{c}0.0 \\
(0.707)^{\mathrm{d}}\end{array}$ & $43.05^{\mathrm{c}}$ & \\
\hline $\mathrm{CD}(P=0.05)$ & 2.485 & 1.849 & 0.167 & 27.28 & 1.374 & 2.086 & \\
\hline $\mathrm{CV} \%$ & 18.68 & 26.368 & 5.868 & 52.06 & 29.91 & 5.04 & \\
\hline
\end{tabular}

Values in parentheses are square root transformations; Mean values marked with same alphabets are significantly not different; ESB: Early shoot borer; INB: Internode borer; DH: Dead-heart

compared with $17.2 \%$ by the non- adaptive strain in an insect cage study. Tests indicated that adaptation to low temperatures led to better host searching and such strain could be successfully utilized under a low temperature regime. Effect of releasing T. chilonis on yield of sugarcane was significant between treatments i.e. T. chilonis releases at different rates and frequency during 2015 and 2016. The results showed that 6 releases of T. chilonis @ 75,000/ha/week, starting from 30 
Table 2. Relative percentage of Trichogramma chilonis recovered from egg masses of sentinel cards during 2016

\begin{tabular}{|c|c|c|c|c|c|c|c|c|}
\hline \multirow{3}{*}{ Treatment } & \multirow{3}{*}{$\begin{array}{l}\mathrm{ESB} \\
(\% \mathrm{DH})\end{array}$} & \multirow{3}{*}{$\begin{array}{l}\text { INB } \\
\text { damage } \\
(\%)\end{array}$} & \multicolumn{4}{|c|}{ T. chilonis field recovery (\%) } & \multirow{3}{*}{$\begin{array}{l}\text { Cane } \\
\text { yield (t/ } \\
\text { ha) }\end{array}$} & \multirow{3}{*}{$\begin{array}{l}\text { Yield } \\
\text { In-crease } \\
(\%)\end{array}$} \\
\hline & & & \multirow{2}{*}{\begin{tabular}{|l}
$\begin{array}{l}\text { Pre-monsoon } \\
\text { period } 2016\end{array}$ \\
$\begin{array}{l}\text { First week } \\
\text { June }\end{array}$
\end{tabular}} & \multirow{2}{*}{$\begin{array}{l}\begin{array}{l}\text { Mon-soon } \\
\text { period } \\
2016\end{array} \\
\begin{array}{l}\text { Last week } \\
\text { June }\end{array}\end{array}$} & \multicolumn{2}{|c|}{$\begin{array}{l}\text { Post-monsoon } \\
\text { period } 2016\end{array}$} & & \\
\hline & & & & & \begin{tabular}{|l} 
Last \\
week \\
July \\
\end{tabular} & $\begin{array}{l}\text { Third } \\
\text { week } \\
\text { October } \\
\end{array}$ & & \\
\hline $\begin{array}{l}\mathrm{T} 1 \text { : T. chilonis } \\
\text { release @ } 50,000 / \\
\text { ha/release, } 4 \text { times } \\
\text { from } 30 \text { days after } \\
\text { planting and } 2 \\
\text { times at node } \\
\text { forma-tion at } \\
\text { weekly interval }\end{array}$ & $4.62^{\mathrm{b}}$ & $7.77^{\mathrm{b}}$ & $6.29(2.605)^{b}$ & $4.43^{\mathrm{c}}$ & $1.74^{\mathrm{d}}$ & $25.88^{\mathrm{c}}$ & $40.21^{\mathrm{cd}}$ & 4.52 \\
\hline $\begin{array}{l}\text { T2: T. chilonis } \\
\text { release @ } 50,000 / \\
\text { ha/release, } 6 \text { times } \\
\text { from } 30 \text { days after } \\
\text { planting and } 2 \\
\text { times at node } \\
\text { forma-tion at } \\
\text { weekly interval }\end{array}$ & $3.64^{\mathrm{c}}$ & $7.81^{b}$ & $5.88(2.525)^{\mathrm{c}}$ & $5.17^{b}$ & $3.85^{\mathrm{c}}$ & $33.85^{\mathrm{b}}$ & $40.92^{\mathrm{bc}}$ & 6.37 \\
\hline $\begin{array}{l}\text { T3: T. chilonis } \\
\text { release @ } 75,000 / \\
\text { ha/release, } 4 \text { times } \\
\text { from } 30 \text { days after } \\
\text { planting and } 2 \\
\text { times at node } \\
\text { forma-tion at } \\
\text { weekly interval }\end{array}$ & $3.16^{\mathrm{c}}$ & $7.28^{\mathrm{b}}$ & $6.38(2.622)^{b}$ & $4.75^{\mathrm{bc}}$ & $10.88^{\mathrm{b}}$ & $36.6^{\mathrm{a}}$ & $42.48^{b}$ & 10.42 \\
\hline $\begin{array}{l}\text { T4: T. chilonis } \\
\text { release @ } 75,000 / \\
\text { ha/release, } 6 \text { times } \\
\text { from } 30 \text { days after } \\
\text { planting and } 2 \\
\text { times at node } \\
\text { forma-tion at } \\
\text { weekly interval }\end{array}$ & $2.27^{\mathrm{d}}$ & $5.85^{\mathrm{c}}$ & $9.27(3.125)^{\mathrm{a}}$ & $17.47^{\mathrm{a}}$ & $20.0^{\mathrm{a}}$ & $37.59^{\mathrm{a}}$ & $47.95^{\mathrm{a}}$ & 24.64 \\
\hline $\begin{array}{l}\text { T5: Untreated } \\
\text { control }\end{array}$ & $15.95^{\mathrm{a}}$ & $18.25^{\mathrm{a}}$ & $0.0(0.707)^{\mathrm{d}}$ & $0.88^{\mathrm{d}}$ & $0.98^{\mathrm{d}}$ & $1.10^{\mathrm{d}}$ & $38.47^{\mathrm{d}}$ & \\
\hline $\mathrm{CD}(P=0.05)$ & 0.714 & 0.759 & 0.074 & 0.644 & 0.916 & 1.221 & 2.038 & \\
\hline $\mathrm{CV} \%$ & 8.986 & 6.026 & 2.368 & 7.346 & 9.07 & 3.37 & 3.619 & \\
\hline
\end{tabular}

Values in parentheses are square root transformations; Mean values marked with same alphabets are significantly not different; ESB: Early shoot borer; INB: Internode borer; DH: Dead-heart 
(DAP) and two times at node formation at 7-10 day interval effectively reduced shoot borers and increased cane yields by $21.7 \%$ during 2015-16 (yield 52.42 t/ha) and 24.64\% during 2016-17 (yield $47.95 \mathrm{t} / \mathrm{ha}$ ) as compared to control (43.05 t/ ha during 2015 and $38.47 \mathrm{t} /$ ha during 2016). Similar studies conducted at Jorhat, on rice against stem borer and leaf folder revealed that the release of $T$. japonicum during dry season played a significant role in the reduction of stem borer (Das, 2004).

Inundative releases of $T$. chilonis @ 75,000/ha/release, 6 times from 30 days after planting and 2 times at node formation stage at weekly intervals proved to be the best treatment followed by T. chilonis@75,000/ha/release 4 times from 30 days after planting and 2 times at node formation stage at weekly intervals, for managing early shoot borer and internode borer in sugarcane. Weather conditions prevailing during monsoon period and post monsoon periods are favourable for the sustainability of the parasitoid compared to pre monsoon period. Efficacy of Trichogramma in the field vary with the timing of release, frequency and rate of release and the performance is influenced by weather conditions, stage of the crop and host insect . Natural enemies generally closely follow the pest population in a stable crop system like sugarcane. Thus, Crop- pest- natural enemy equilibrium should be given due consideration in planning control measures. The stable crop system and low pesticide load provide ideal conditions for both natural and applied biological control.

\section{ACKNOWLEDGEMENTS}

First author is thankful to Director of Research, Acharya NG Ranga Agricultural University, Andhra Pradesh, for financial assistance and also thankful to the Director, NBAIR,
Bangalore, for providing technical support for conducting studies.

\section{REFERENCES}

Bing HC, Jih ZZ. 1996. Effect of releasing Trichogramma embryophagum (Hymenoptera: Trichogrammatidae) on controlling asian corn borer (Lepidoptera: Pyralidae) in Taiwan. J Asian Res China 45: 401-410.

Das DJ. 2004. Establishment and recovery of Trichogramma chilonis Ishii on certain rice varieties. Shashpa 1: 45-50.

Jalali SK, Murthy KS, Venkatesan T, Lalitha Y, Devi PS. 2006a. Adaptive performance of Trichogramma chilonis Ishii at low temperature. Ann Pl Prot Sci. 14: 5-7.

Jalali SK, Singh SP. 2006.Temparature dependant developmental biology of maize stalk borer, Chilo partellus (Swinhoe) (Lepidoptera: Pyralidae) and its natural enemies. Indian J Entomol. 68: 54-61.

Narasimha Rao ChV, Venugopala Rao N, Bhavani B. 2006. Efficacy of Trichogramma chilonis Ishii against early shoot borer, Chilo infuscatellus Snellen under sugar factory operational areas of Coastal Andhra Pradesh. J Biol Control 20: 225-228.

O’Malley B. 2005. Collected from internet articles from News limited Australian papers.

Somchoudhury AK, Dutt N.1980. Field bioecology of Trichogramma perkinse Girault and Trichogramma australicum Giaraut(Hymenoptera:Trichogrammatidae) and their time of release for the control of Chilo partellus (Swinhoe) and Heliothis armigera Hubn. J Enomol. Res. 4: 73-82. 